\title{
Evaluation of serum mineral status and hormone profile in goats and some of their inter-relations
}

\author{
Mohd Iqbal Yatoo ${ }^{1}$, Archana Saxena ${ }^{2}$, Pankaj Kumar ${ }^{3}$, Mudasir Bashir Gugjoo ${ }^{4}$, Umesh Dimri ${ }^{1}$, \\ Mahesh Chandra Sharma ${ }^{5}$ and Ricky Jhambh ${ }^{1}$
}

\begin{abstract}
1. Division of Medicine, Indian Veterinary Research Institute (IVRI), Izatnagar, Bareilly, U.P.-243122, India; 2. Division of Molecular Bio-prospection, CSIR-CIMAP, Lucknow-226015, India; 3. ICAR-RCER Patna, Bihar-800014, India; 4. Division of Surgery, IVRI, Izatnagar, Bareilly, U.P.-243122, India; 5. ICAR HQ, New Delhi-110 001, India Corresponding author: Mohd Iqbal Yatoo, email:iqbalyatoo@gmail.com
\end{abstract} Received: 29-09-2012, Accepted: 18-11-2012, Published online: 11-03-2013

How to cite this article: Yatoo MI, Saxena A, Kumar P, Gugjoo MB, Dimri U, Sharma MC and J hambh R (2013) Evaluation of serum mineral status and hormone profile in goats and some of their inter-relations, Vet. World 6(6):318-320, doi: 10.5455/ vetworld.2013.318-320

\begin{abstract}
Aim: The present study was carried out with the objective to estimate the serum mineral status, and hormonal profile of goats in Kashmir valley.

Materials and Methods: Thirty female goats $(n=30)$ were selected randomly from three districts (ten from each district) of Kashmir valley. Serum minerals were estimated by atomic absorption spectrophotometry and hormones by radioimmunoassay (RIA) technique using gamma scintillation counter ( $\mathrm{I}^{125}$ calibrated), at Nuclear Research Laboratory, IVRI, Izatnagar.

Results: Mean \pm SE value of calcium $(\mathrm{Ca})$, phosphorus $(\mathrm{P})$, magnesium $(\mathrm{Mg})$ was $10.46 \pm 0.76,5.12 \pm 0.31,2.11 \pm 0.24 \mathrm{mg} / \mathrm{dl}$ respectively, whereas copper $(\mathrm{Cu}$, ) iron $(\mathrm{Fe})$, zinc $(\mathrm{Zn})$ and cobalt $(\mathrm{Co})$ was $0.548 \pm 0.094,1.548 \pm 0.173,0.864 \pm 0.211$ and $0.027 \pm 0.003 \mathrm{ppm}$, respectively. Non-significant $(\mathrm{p}<0.01)$ difference was found in the serum mineral concentrations between and within the goat of different districts. Serum mineral concentrations in goat were in slightly deficient range. Mean $\pm \mathrm{SE}$ value of serum estrogen $\left(\mathrm{E}_{2}\right)$ in $\mathrm{pg} / \mathrm{ml}$, progesterone $\left(\mathrm{P}_{4}\right)$, triiodothyronin $\left(\mathrm{T}_{3}\right)$ and tetraiodothyronin $\left(\mathrm{T}_{4}\right) \mathrm{in} \mathrm{ng} / \mathrm{ml}$ of goat was $19.35 \pm 0.45,1.37 \pm 0.141,1.16 \pm 0.163$ and $31.09 \pm 1.15$, respectively. Steroid and thyroid hormone levels were towards the lower side of the normal range. Wide variations were noted in the correlations between serum minerals and steroid and thyroid hormones indicating diverse interrelations between minerals and hormones.
\end{abstract}

Conclusion: Most of the animals showed deficient serum mineral status. Mineral deficiency affects hormone status and impairs production potential of animals. Based on these findings supplementation of mineral to goat of Kashmir valley is imperative.

Keywords: goat, hormones, Kashmir valley, minerals

\section{I ntroduction}

Minerals and mineral-hormone interactions in the serum of small ruminants have not been worked well especially in developing countries where mineral deficiencies are of more significant consequence than infectious diseases [1,2]. Minerals are required for normal functioning of basically all biochemical processes in the body [3]. Minerals act as catalysts in both enzyme and hormone systems [4]. Metalloenzymes, of which essential minerals are constituents, are important in the synthesis of many steroid hormones [5,6] and thyroid hormones [3,7]. Such role of minerals in goats has not been studied well.

\section{Materials and Methods}

The study area of Kashmir lies between $33^{\circ} 21^{\prime}$ to $34^{\circ} 55^{\prime} \mathrm{N}$ latitude and $73^{\circ} 30^{\prime}$ to $75^{\circ} 35^{\prime} \mathrm{E}$ longitude and is characterized by sub-humid temperate climate. A total of 30 nondescript goats were randomly selected for the

This article is an open access article licensed under the terms of the Creative Commons Attribution License (http://creativecommons. org/licenses/by/2.0) which permits unrestricted use, distribution and reproduction in any medium, provided the work is properly cited. survey purpose from three districts (Budgam, Pulwama and Srinagar) of Kashmir valley (ten from each district). All the selected animals were females in the age group of 1-3 year, grazing same pastures and reared under similar managemental conditions.

Blood samples were collected by jugular venipuncture, $2 \mathrm{ml}$ in heparinized tubes for hematological estimations and $3 \mathrm{ml}$ in tubes without any anti-coagulant for harvesting serum. The separated serum was stored at $-20^{\circ} \mathrm{C}$ pending analysis of minerals, hormones, enzymes and biochemical.

Calcium, magnesium, copper, iron, zinc and cobalt were estimated by atomic absorption spectrophotometry after digesting the serum samples by the procedure of Kolmer et al. [8]. AAS (Model No. AAS 4141) manufactured by Electronic Corporation of India (ECIL), Hyderabad was used in present investigation. Phosphorus was estimated by the method of Taussky and Shorr [9] using test kits provided by Span Diagnostics Ltd. India. Serum estrogen $\left(\mathrm{E}_{2}\right)$, progesterone $\left(\mathrm{P}_{4}\right)$, triiodothyronin $\left(\mathrm{T}_{3}\right)$ and tetraiodothyronin $\left(\mathrm{T}_{4}\right)$ was determined by radioimmunoassay (RIA) technique using gamma 
Table-1. Serum mineral status of goats in different districts.

\begin{tabular}{|c|c|c|c|c|}
\hline Mineral & $\begin{array}{l}\text { Budgam } \\
\text { MeantSE }\end{array}$ & $\begin{array}{l}\text { Pulwama } \\
\text { Mean_SE }\end{array}$ & $\begin{array}{l}\text { Srinagar } \\
\text { Mean+SE }\end{array}$ & $\begin{array}{l}\text { Total } \\
\text { Mean+SE }\end{array}$ \\
\hline Calcium (Ca) & $11.98 \pm 0.85$ & $9.07 \pm 0.75$ & $10.04 \pm 0.81$ & $10.46 \pm 0.76$ \\
\hline Phosphorus (P) & $6.06 \pm 0.43$ & $5.02 \pm 0.40$ & $4.52 \pm 0.38$ & $5.12 \pm 0.31$ \\
\hline Magnesium (Mg) & $1.99 \pm 0.16$ & $2.01 \pm 0.21$ & $2.22 \pm 0.25$ & $2.11 \pm 0.24$ \\
\hline Copper $(\mathrm{Cu})$ & $0.621 \pm 0.110$ & $0.523 \pm 0.091$ & $0.491 \pm 0.089$ & $0.548 \pm 0.094$ \\
\hline Iron (Fe) & $1.482 \pm 0.142$ & $1.521 \pm 0.170$ & $1.542 \pm 0.169$ & $1.548 \pm 0.173$ \\
\hline Zinc $(Z n)$ & $0.882 \pm 0.199$ & $0.764 \pm 0.186$ & $0.862 \pm 0.221$ & $0.864 \pm 0.211$ \\
\hline Cobalt (Co) & $0.029 \pm 0.0033$ & $0.026 \pm 0.0029$ & $0.027 \pm 0.0031$ & $0.027 \pm 0.0032$ \\
\hline
\end{tabular}

Table-2. Steroid and thyroid hormone profile of goats in different districts.

\begin{tabular}{|c|c|c|c|c|}
\hline Mineral & $\begin{array}{l}\text { Budgam } \\
\text { MeantSE }\end{array}$ & $\begin{array}{l}\text { Pulwama } \\
\text { Mean_SE }\end{array}$ & $\begin{array}{l}\text { Srinagar } \\
\text { MeantSE }\end{array}$ & $\begin{array}{l}\text { Total } \\
\text { Mean+SE }\end{array}$ \\
\hline Estrogen $\left(E_{2}\right) \mathrm{pg} / \mathrm{ml}$ & $18.67 \pm 0.40$ & $20.13 \pm 0.51$ & $19.21 \pm 0.43$ & $19.35 \pm 0.45$ \\
\hline Progesterone $\left(\mathrm{P}_{4}\right) \mathrm{ng} / \mathrm{ml}$ & $1.34 \pm 0.139$ & $1.42 \pm 0.142$ & $1.26 \pm 0.12$ & $21.37 \pm 0.141$ \\
\hline Triiodothyronine $\left(\mathrm{T}_{3}\right) \mathrm{ng} / \mathrm{ml}$ & $1.13 \pm 0.168$ & $1.19 \pm 0.177$ & $1.15 \pm 0.160$ & $1.16 \pm 0.163$ \\
\hline Tetraiodothyronin $\left(\mathrm{T}_{4}\right) \mathrm{ng} / \mathrm{ml}$ & $32.21 \pm 1.01$ & $30.08 \pm 1.12$ & $31.12 \pm 1.18$ & $31.09 \pm 1.15$ \\
\hline
\end{tabular}

Table-3. Correlation coefficient between minerals and hormones.

\begin{tabular}{lcccc}
\hline & Estrogen $\left(\mathbf{E}_{\mathbf{2}}\right)$ & Progesterone $\mathbf{(}_{\mathbf{4}} \mathbf{)}$ & Triodothyronine $\left(\mathbf{T}_{\mathbf{3}}\right)$ & Tetraiodothyronin $\left(\mathbf{T}_{\mathbf{4}}\right)$ \\
\hline Calcium $(\mathrm{Ca})$ & 0.48 & 0.51 & 0.16 & 0.14 \\
Phosphorus (P) & 0.43 & 0.46 & 0.28 & 0.17 \\
Magnesium (Mg) & 0.22 & 0.16 & 0.14 & 0.12 \\
Copper (Cu) & $0.54^{*}$ & $0.58^{*}$ & 0.55 & 0.52 \\
Iron (Fe) & 0.48 & 0.44 & $0.52^{*}$ & $0.50^{*}$ \\
Zinc (Zn) & $0.62^{*}$ & -0.41 & 0.45 & 0.41 \\
Cobalt (Co) & 0.31 & 0.23 & 0.20 & 0.21 \\
\hline
\end{tabular}

*significant correlation $(p<0.05)$.

scintillation counter ( $\mathrm{I}^{125}$ calibrated), at Nuclear Research Laboratory, Division of Physiology \& Climatology, IVRI, Izatnagar. Estradiol, $\mathrm{T}_{3}$ and $\mathrm{T}_{4}$ radioimmuno assay kits were obtained from Immunotech, France whereas progesterone radioimmunoassay kit was obtained from Bhabha Atomic Research Centre (BARC), India.

Statistical analysis: Data collected from this study were analyzed as per the method described by Snedecor and Cochran [10] for mean, standard error, analysis of variance (ANOVA) and correlation coefficient by standard ' $t$ ' test.

Ethical approval: The research was approved by Institutional Animal Ethics Committee.

\section{Results}

Mean \pm SE of serum mineral content of goat is given in Table-1. Mean \pm SE of serum estrogen $\left(E_{2}\right)$ in $\mathrm{pg} / \mathrm{ml}$, progesterone $\left(\mathrm{P}_{4}\right)$ in $\mathrm{ng} / \mathrm{ml}$, tetraiodothyronin $\left(\mathrm{T}_{4}\right) \mathrm{in} \mathrm{ng} / \mathrm{ml}$ and triiodothyronin $\left(\mathrm{T}_{3}\right) \mathrm{in} \mathrm{ng} / \mathrm{ml}$ of goat is given in Table- 2 .

Correlation determined between serum mineral concentrations and the levels of steroid and thyroid hormones in goats is summarized in Table-3. Positive but non-significant $(p<0.05)$ correlation was found between calcium, phosphorus and magnesium and estrogen and progesterone. Copper showed positive and significant $(p<0.05)$ correlation between estrogen and progesterone. Positive and significant $(p<0.05)$ correlation was found between zinc and estrogen but negative and non-significant $(p<0.05)$ correlation was found between zinc and progesterone. Positive but non-significant $(p<0.05)$ correlation was found between iron and estrogen and progesterone in goats. Positive but non-significant $(p<0.05)$ correlation was found between cobalt and estrogen and progesterone in goats.

\section{Discussion}

Calcium, phosphorus and magnesium were slightly towards lower side of normal range in goats. Khan et al. [11] and Sowande et al. [12] reported adequate calcium, phosphorus and magnesium in goats. Non-significant $(p<0.01)$ difference was found in the serum mineral concentration of goats between the districts. However most of the minerals were in deficient status as compared to their respective critical levels $[13,14]$. Similar findings were made by Khan et al. [15] who reported that overall mineral status of goats grazing the same types of pastures was inadequate. Shinde et al. [16] reported normal serum $\mathrm{Ca}$ and $\mathrm{Mg}$ levels but low P levels in goats. Also they found low levels of $\mathrm{Cu}$ and elevated levels of $\mathrm{Zn}$. Significantly low levels of $\mathrm{Fe}$ and $\mathrm{Zn}$ concentration was observed in goats by Kalita et al. [17]. Microminerals in goats were also studied by Booshan etal. [18].

Serum hormone levels were in normal range. Similar results for mean estradiol level in AngloNubian does were reported by Blaszczyk et al. [19]. Todini et al. [20] found similar mean values of $\mathrm{T}_{3}$ and $\mathrm{T}_{4}$ concentrations in goats.

The correlation among the mineral and hormones can be inferred by different reasons. Calcium is involved in the synthesis of steroid hormones in ovaries and adrenal glands and the release of 
luteinizing hormone from the pituitary gland [21]. Positive correlation was observed between serum progesterone level and copper-zinc in cow and heifer throughout the oestrus cycle [22]. Progesterone secretion was impaired due to a copper deficiency during the oestrus cycle and especially in late pregnancy in ewes [23]. Kandzere et al. [24] reported negative correlation between plasma progesterone and zinc during dry period in goats. Zinc deficiency results in alteration of steroidogenesis [5]. Gottsch et al. [25] suggested the role of zinc in the reorganization of ovarian follicle, source of progesterone through the involvement of metalloproteinase-2 (MMP-2), member of zinc endopeptidase family. El-Marsy and Nasr [26] reported increase in plasma progesterone and oestradiol-17 beta level after supplementation with iron. Cobalt deficient goats showed prolonged oestrous cycle and altered progesterone levels [27].

\section{Conclusion}

Most of the animals showed deficient serum mineral status. Mineral deficiency affects hormone status and impairs production potential of animals. Based on these findings, supplementation of mineral to goat of Kashmir valley is imperative.

\section{Authors' contribution}

MIY implemented the study design. MCS, UD and PK provided the necessary guidance and drafted and revised manuscript. MBG, RJ and AS helped in the sample collection and laboratory estimations. All authors read and approved the final manuscript.

\section{Acknowledgements}

Authors are thankful to Director IVRI, Izatnagar for providing all the necessary facilities.

\section{Competing interests}

Authors declare that they have no competing interests.

\section{References}

1. McDowell, L.R. (1985) Nutrition of grazing ruminants in warm climates. Academic Press Inc. San Diego CA. pp. 168169.

2. Soetan, K.O., Olaiya, C.O. and Oyewole, O.E. (2010) The importance of mineral elements for humans, domestic animals and plants - A review. Afr. J. Food Sci. 4(5): 200-222.

3. Suttle, N.F. (2010) Mineral Nutrition of Livestock, 4th Edition. Cabi Publishing, USA.

4. Ceylan, A., Serin, I., Aksit, H. and Seyrek, K. (2008) Concentrations of some elements in dairy cows with reproductive disorders. The Bulletin of the Veterinary Institute in Pulawy. 52: 109-112.

5. Yamaguchi, S., Miura, C., Kikuchi, K., Celino, F.T., Agusa, T., Tanabe, S. and Miura, T. (2009) Zinc an essential trace element for spermatogenesis. Proceedings of the National Academy of Sciences of United States of America. 106: 10859-10864.

6. Yokus B., Cakir D., Icen, H., Durak, H. and Bademkiran S. (2010) Prepartum and Postpartum Serum Mineral and Steroid Hormone Concentrations in Cows with Dystocia. Veteriner Fakultesi Dergisi. 21 (3): 185 - 190.

7. Hess S.Y. and Zimmermann M. B. (2004) The effect of micronutrient deficiencies on iodine nutrition and thyroid metabolism. Inter. J.Vit.Nutr. Res. 74: 103-115.

8. Kolmer, J.A., Spanbling E.H. and Robinson H.W. (1951) Approved Laboratory Technique. Appleton Century Crofts, New York.

9. Taussky, H.H. and Shorr, E. (1953) A microcolorimetric method for the determination of inorganicphosphorus. $J$. Biol. Chem.202: 675-685.

10. Snedecor, G.W. and Cochran, W.G. (1994) Statistical Methods. $6^{\text {th }}$ Edn. Iowa State University Press. Ames, Iowa.

11. Khan, Z.I., Ashraf, M., Ahmad, K., Ahmad, N., Danish, M. and Valeem, E.E. (2009) Mineral composition of forages for ruminants in Pakistan. Pak. J. Bot. 41(5): 2465-2476.

12. Sowande, O.S., Odufowora, E.B., Adelakun, A.O. and Egbeyale, L.T. (2008) Blood minerals in Wad sheep and goats grazing natural pastures during wet and dry seasons. Archivos de Zootecnia. 57 (218): 275-278.

13. Lundu T., Choongo K., Munyinda K., Walubita K. and Siulapwa N. J. (2012) A survey of seasonal macro-mineral status of soil, plants and goats in Siavonga, southern Zambia. Livestock Research for Rural Development. Volume 24, Article\#76.

14. Smith M. C. and Sherman D. M. (2011) Goat Medicine, Second Edition. Blackwell Publishing, New York, USA.

15. Khan, Z.I., Ashraf, K.M., Ahmad, K., Valeem, E.E. and McDowell, L.R. (2009) Mineral status of forage and its relationship with that of plasma of farm animals in southern Punjab, Pakistan. Pak. J. Bot. 41: 67-72.

16. Shinde, A.K. and Sankhyan, S.K. (2007). Mineral profile of cattle, buffaloes, sheep and goats reared in humid southerneastern plains of semiarid Rajasthan. Indian J. Small Rumin. 13(1): 39-44.

17. Kalita, D.J., Sarmah, B.C., Bhattacharyya, B.N. and Milli, D.C. (2006) Serum mineral profile of assam local goat of hills zone during different physiological stages. Indian $J$. Anim. Res. 40(1): 93 - 94.

18. Bhooshan N., Kumar, P. and Yadav, M.C. (2010) Microminerals status in goats of different age in semi-arid region of India. Indian J. Anim. Sci. 80 (3): 258-261.

19. Blaszczyk, B., Udala, J. and Gaczarzewicz, D. (2004) Changes in estradiol, progesterone, melatonin, prolactin and thyroxin concentrations in blood plasma of goats following induced estrus in and outside the natural breeding season. Small Rum. Res. 51:209-219.

20. Todini, L., Delgadillo, J.A., Debenedetti, A. and Chemineau, P. (2006) Plasma total $T_{3}$ and $T_{4}$ concentrations in bucks as affected by photoperiod. Small Rum. Res. 65(1-2): 8-13.

21. Hurley, W.L. and Doane R.M. (1989) Recent development in the roles of vitamin and minerals in reproduction. J. Dairy Sci.72: 784-804.

22. Yildiz, H. and Akar Y. (2001) Relationships between serum progesterone and some mineral levels during the oestrous cycles in cows. Saglik-Bilimleri-Dergisi-Firat-universities. 15: 77-84.

23. Van Niekerk, F. E. and Van Niekerk, C.H. (1989) The influence of experimentally induced copper deficiency on the fertility of rams II. Macro and microscopic changes in the testes. J. South Afri. Vet. Assoc. 60: 28-31.

24. Kandreze, C.T., Lelewelyn, C.A. and Chivandi, E. (1997) Plasma progesterone, calcium, magnesium and zinc concentrations from oestrus synchronization to weaning in indigenous goats in Zimbabwe. Small Rumin. Res. 24: 21-26.

25. Gottsch, M.L., Murdoch, W.J. and Van Kirk, E.A. (2000) Tumour necrosis factor alpha upregulates matrix metalloproteinase- 2 activity in preovulatory ovine fooliclesb metamorphic and endocrine implications. J. Reprod. Fert. Develop. 12: 75-80.

26. El-Marsy, K. A. and Nasr, A. S., (1996) The role of folic acid and iron in reproductive performance of New Zealand white does and their kids. World Rabbit Science. 4: 127-131.

27. Mgongo, F. O. K. (1988) Stress of nutritional origin and its effects on peripheral concentration of plasma hormones in goats. Indian Vet. J. 65: 486-490.

$* * * * * * * *$ 